\title{
Evaluasi Peraturan Daerah Kota Pekanbaru Nomor 9 Tahun 2014 Tentang Pengelolaan Pasar Rakyat, Pusat Perbelanjaan dan Toko Swalayan pada Dinas Perdagangan dan Perindustrian (Studi Kasus Perencanaan Fisik Pasar Sail di Kecamatan Sail)
}

\author{
Elly Nielwaty \\ Universitas Lancang Kuning, Riau, Indonesia \\ nielwaty@gmail.com
}

\begin{abstract}
This research discusses the evaluation of the Pekanbaru City Regional Regulation Number 9 of 2014. Every people's market must meet the requirements starting from the supporting facilities and facilities that must exist in the people's market according to those already in the policy, while at Sail Market there are supporting facilities and facilities which are not available or many are not functioning due to lack of maintenance from the manager. The theory used is Riant Nugroho's evaluation theory which suggests an evaluation of policy performance. The place of this research is the Department of Trade and Industry of Pekanbaru City and Sail Market. The purpose of this study is to evaluate the Regional Regulation Number 9 of 2014 on the physical planning of Sail market. This research uses a descriptive qualitative method, this method is used to describe how the Pekanbaru City government manages and supervises the people's market, especially the Sail Market. The results of this study conclude that the Pekanbaru City government in dealing with people's markets managed by third parties to create a decent, safe and healthy people's market according to the provisions of Regional Regulation No. 9 of 2014 has not been effective. The Department of Trade and Industry has not been able to carry out its duties and functions as the agency responsible for managing the people's market. This is because the current condition of Sail market is that there are many supporting facilities and facilities that do not exist.
\end{abstract}

Keywords: Evaluation; policy; physical planning

\section{Pendahuluan}

Pekanbaru sebagai Ibu Kota Provinsi Riau dijuluki Kota Madani, setiap tahun banyak masyarakat dari luar daerah yang menjadi pendatang sementara dan menetap di Kota Pekanbaru. Hal ini membuat pembangunan berkembang sangat pesat diberbagai sektor mulai dari pembangunan fisik seperti pembangunan fasilitas umum, rumah sakit, jalan raya, jembatan, pusat perbelanjaan, toko dan sebagainya. Pembangunan pada hakikatnya merupakan suatu upaya perubahan yang direncanakan secara sadar dan berkelanjutan dengan tujuan yang lebih baik dan bernilai (Yandra, 2016). Pembangunan ini banyak yang dilakukan oleh daerah sendiri untuk kebutuhan pribadinya, saat melakuan pembangunan ada hal-hal yang di perhatikan terkait pembangnan itu sendiri. Seperti sumber daya manusia, sumber daya alam dan kegunaan dari pembangunan itu sendiri apakah pembangunan itu sudah tepat sasaran atau apakah pembangunan itu sudah sesuai dengan kebutuhkan. Pembangunan bisa dilakukan oleh pemerintah itu sendiri atau dengan perjanjian pihak ketiga yang pengelolaannya harus tetap di bawah pengawasan pemerintah itu sendiri.

Kebijakan adalah pernyataan pemerintah atas suatu aturan yang dibuat untuk menyelesaikan masalahn publik tertentu. Setiap hal yang ada dalam kebijakan harus mendapat legitimasi pembenaran hukum atau sesuai dengan tata peraturan dan perundang-undangan yang 
berlaku. Setelah kebijakan itu dibuat maka dilaksanakan oleh orang-orang yang terlibat baik secara langsung atau tidak langsung untuk mencapai tujuan yang sudah ditentukan dari awal, lalu untuk memastikan pelaksanaan kebijakan itu perlu adanya peninjauan kembali proses dan hasil yang telah di capai selama kebijakan itu di buat.

Evaluasi kinerja kebijakan untuk mengukur sejauh mana pelaksanaan kebijakan tersebut, dan kepada siapa kebijakan itu di laksanakan. Arti penting evaluasi bukanlah sebuah tahap untuk menyalah-nyalahkan, tetapi untuk mengamati seberapa besar kesejangan antara harapan dan kenyataan setelah kebijakan itu di impementasikan. Setelah menemukan kesenjangan maka dilakukan usaha untuk menutup atau memperbaiki kesenjangan tersebut yang artinya evaluasi merupakan usaha yang bersifat positif.

Perencanaan merupakan tahap menentukan langkah-langkah yang akan dilakukan sebuah pembangunan, dalam perencanaan harus ada sumber daya yang digunakan. Perencanaan juga harus dilatarbelakangi oleh adanya tuntutan agar dilakukannya pembangunan untuk tujuan tertentu. Dalam perencanaan fisik harus ada sumber daya alam yang digunakan dan sumber daya manusia untuk melaksanakan rencana tersebut.

Dinas Perdagangan dan Perindustrian merupakan dinas yang bertanggung jawab dan berwenang pihak penanggung jawab pada bidang perdagangan dan Perindustrian. Pasar rakyat merupakan tempat bertemunya penjual dan pembeli secara langsung dan biasanya ada proses tawar menawar yang menjadi ciri khas pasar tradisional, di pasar tradisional biasanya bangunanya terdisi dari kios-kios, gerai, dan konter terbuka yang di buka oleh penjual berdasarkan tempat yang disediakan oleh pengelola tempat tersebut. Pusat perbelanjaan adalah suatu kawasan yang terdiri dari beberapa bangunan yang di bangun secara luas,pada kawasan pusat perbelanjaan bangunan di sewakan dan dijual kepada pelaku usaha untuk dikelola sendiri dalam melakukan kegiatan jual beli kepada pembeli. Toko swalayan atau supermarket merupakan sebuah toko yang menjual segala kebutuhan sehari-haridengan sistem pelayanan mandiri yang dibantu oleh pramuniaga.

Pasar Sail pertama kali dibangun Tahun 1975 menggunakan dana dari swadaya masyarakat, dana inpres dan pemerintah Kota Pekanbaru di lahan seluas $+5.540 \mathrm{~m}^{2}$. Pasar yang dibangun di atas tanah milik pemerintah dan kondisinya dulu belum seperti sekarang. Lalu seiring dengan waktu dan pertumbuhan penduduk dalam memenuhi kebutuhannya, tahun 2000 pemerintah akhirnya melakukan MoU dengan PT.Riau Kerta Raharja sebagai pihak ketiga sekaligus investor untuk membangun dan mengelola Pasar Sail seperti sekarang, yaitu Pasar Sail yang lebih nyaman dan fasilitas yang lebih lengkap. Pasar Sail sendiri sekarang memiliki bangunan dua lantai yang terdiri dari 178 kios, 126 los dan 11 konter. Pasar Sail mulai beroperasi tahun 2002, kerjasama antara pemerintah dan PT.Riau Kerta Raharja berlangsung selama 20 tahun hingga tahun 2022 dan nanti akan dilakukan evaluasi mengenai pengelolaan selanjutnya.

Dalam pasal 9 disebutkan sarana pendukung pasar antara lain :

Tabel 1

Data Sarana Pendukung Pada Pasar Sail

\begin{tabular}{|c|c|c|c|}
\hline No. & Jenis & Ada/Tidak Ada & Keterangan \\
\hline 1. & $\begin{array}{l}\text { Kemetrologian/ } \\
\text { Penteraan }\end{array}$ & Tidak ada & $\begin{array}{l}\text { Alat pengukur akurasi } \\
\text { timbangan ini bisa } \\
\text { disediakan pengelola atau } \\
\text { pemerintah. }\end{array}$ \\
\hline 2. & Sarana Komunikasi & Tidak ada & _ \\
\hline
\end{tabular}




\begin{tabular}{lll} 
3. & $\begin{array}{l}\text { Area Bongkar } \\
\text { Muat }\end{array}$ & Tidak ada \\
4. & $\begin{array}{l}\text { Ruang Terbuka } \\
\text { Hijau }\end{array}$ & Tidak ada \\
& $\begin{array}{l}\text { Penitipan Anak/Ibu } \\
\text { 5. }\end{array}$ & Tidak ada \\
& $\begin{array}{l}\text { Tangusui } \\
\text { 6. }\end{array}$ & Lift \\
\hline
\end{tabular}

Sumber: PT. Riau Kerta Raharja (2021)

Sarana pendukung merupakan fasilitas yang mendukung agar lebih efektif dan efisien selain fasilitas pokok yang harus dimiliki. Pada Pasar sail sangat disayangkan karena dari 6 sarana pendukung yang seharusnya ada sesuai kebijakan, tetapi Pasar Sail hanya memiliki 1(satu) dan untuk sarana pendukung lainnya biasanya pedagang hanya berusaha memanfaatkan fasilitas yang seperti area bingkar muat dilakukan di area parkir depan pasar, dan area penitipan anak diganti dengan tempat bermain anak yang ada di Pasar Sail milik pedagang dengan membayar tiket masuk. Untuk kemetrologian (alat ukur akurasi timbangan) ini biasanya milik aparat yang bertugas mengawasi jenis timbangan dan tingkat akurasinya. DPP merupakan dinas yang bertugas juga mengawasi hal tersebut untuk menjaga kepercayaan pembeli di Pasar Sail.

\section{Tabel 2}

Kondisi Kios, Los dan Konter Pada Pasar Sail

\begin{tabular}{ccccccc}
\hline No & Jenis & Total & Terisi & kosong & Baik & Rusak \\
\hline 1. & Kios & 178 & 63 & 115 & 88 & 90 \\
2. & Los & 126 & 43 & 83 & 54 & 72 \\
3. & Konter & 11 & 11 & - & 4 & 7 \\
\hline
\end{tabular}

Sumber: PT. Riau Kerta Raharja (2021)

Dari tabel diatas bisa dilihat bahwa jumlah kios dan los yang terisi sangat sedikit, lebih dari setengah kios dan los kosong, serta banyak jugak yang dalam kondisi rusak dan perlu peremejaan. Untuk konter saat ini masih terisi penuh karena konter merupakan tempat kosong yang berada di teras depan pasar sehingga pedagang masih meminati untuk berjualan disana, adapun pedagang yang berjualan di konter seperti pedagang aksesoris, kue-kue dan roti. Kondisi sudah terjadi beberapa tahun belakangan membuat PT. Riau Kerta Raharja mengaku kesulitan melakukan pembenahan pada bangunan pasar. Menurut pengelola pasar sail beberapa alasan penyewa meninggalkan Pasar Sail yaitu akan menyewa tempat pribadi di luar, atau banyak jugak yang beralih menjadi pedagang pasar ilegal.

Penelitian ini bertujuan menganalisis bagaimana evaluasi tentang Peraturan Daerah Kota Pekanbaru No 9 Tahun 2014 Tentang pengelolaaan Pasar Rakyat, Pusat Perbelanjaan Dan Toko Swalayan Pada Dinas Perdagangan Dan Perindustrian (Studi Kasus Perencanaan Fisik Pasar Di Kecamatan Sail) dan kendala dalam pelaksanaannya oleh pemerintah.

\section{Konsep Teori}

Riant Nugroho (2014: 706) menjelaskan evaluasi merupakan penilaian pencapaian kinerja dari implementasi. Riant 
Nugroho (2014: 452) juga mengatakan dari proses evaluasi akan ditemukan fakta terhadap kondisi yang terjadi disebabkan oleh kebijakan tersebut, hubungan antar organisasi dan instansi dapat diketahui melalui pengamatan terhadap implementasi kebijakan tersebut.

Adapun indikator dari evaluasi kinerja kebijakan dilakukan dengan melakukan penilaian menyeluruh menurut Riant Nugroho (2014: 453):

1. Pencapaian target kebijakan (output) dalam jangka pendek

2. Pencapaian tujuan kebijakan (outcome) dalam jangka panjang

3. Kesenjangan antara target dan tujuan dengan pencapaian

4. Membandingkan kebijakan yang sama di tempat yang berhasil

5. Identifikasi faktor pendukung keberhasilan dan kegagalan dan rekomendasi untuk mengatasi kesenjangan

Kebijakan menurut Harbani Pasolong (2013: 38) adalah hasil dari pendalaman pikiran terhadap tata cara yang dianggap paling tepat sebagai alternatif. Menurut Dwiyanto (2017: 55) kebijakan menjadi tempat atau wadah berkumpulnya orangorang dari berbagai pihak untuk memecahkan masalah publik secara adil agar bisa diterima dari pihak yang terlibat dalma permasalahan tersebut. Menurut Baldertun dalam Raharjo Adisasmita (2011: 21) kata lain dari pengelolaan yaitu manajemen yang memiliki arti pemprosesan, pengendalian, dan melakukan suatu kegiatan yang dilakukan orang-orang melalui sarana dan prasarana untuk pencapaian dari sasaran yang telah ditentukan. Menurut Soedarsono dalam Relawati (2012: 52) perencanaan adalah cara atau langkah-langkah dalam mencapai tujuan yang inginkan dan sudah ditentukan sebelum rencana tersebut dilakukan, hal ini merupakan juga bagian dari tahap manajemen.

\section{Metode}

Lokasi penelitian yang dilakukan oleh penulis berada pada Kantor Dinas
Perdagangan dan Perindustrian Kota Pekanbaru Jalan Teratai, No.83, Kelurahan Kedung Sari, Kecamatan Sukajadi Kota Pekanbaru dan Pasar Sail di Kecamatan Sail.

Jenis penelitian ini yaitu penelitian kualitatif, menurut Craswell dalam Jamaluddin (2015: 52) penelitian kualitatif adalah penelitian dengan teknik menjelajahi suatu individu atau kelompok dalam permasalahan publik dalam masyarakat. Teknik yang digunakan bermacam cara mulai dari wawancara, observasi, dokumenasi kepada orang yang terlibat, lalu dipaparkan sesuai tingkat kefokusan permasalahan secara induktif diawali dengan pendekatan empiris lalu analisa data menggunakan teknik terstruktur dan terencana. Penelitian ini bersifat deskriptif yaitu penggambaran secara terperinci dan lengkap terhadap evaluasi peraturan daerah kota Pekanbaru nomor 9 tahun 2014 tentang pengelolaan pasar rakyat, pusat perbelanjaan dan toko swalayan pada Dinas Perdagangan dan Perindustrian terhadap perencanaan fisik Pasar Sail di Kecamatan Sail.

\section{Hasil dan Pembahasan}

Evaluasi Peraturan Daerah Kota Pekanbaru No 9 tahun 2014 pada Dinas Perdagangan dan perindustrian terhadap perencanaan fisik pasar sail ini dapat dilihat dari hasil wawancara sebagai berikut.

\subsection{Pencapaian Target Kebijakan (Output) Dalam Jangka Pendek}

Output merupakan hasil atau produk yang langsung bisa di lihat dan rasakan ketika proses pelaksanaan kebijakan itu dilakukan. Pencapaian ini tentunya dilihat dari hasil pencapaian target yang sudah ditentukan sejak awal proses perumusan lalu pelaksanaannya dalam jangka pendek. Penentuan target dilakukan dengan mengamati siapa-siapa saja yang berhubungan dan kontak langsung dengan kebijakan itu mulai dari pembuat, pelaksana dan yang menerima dampak dari kebijakan tersebut.

Berdasarkan hasil wawancara dengan Kepala Bidang Pasar Dinas Perdagangan 
dan Perindustrian Kota Pekanbaru, beliau menyatakan:

"Kalau masalah kebijakan sebenarnya sistem pengelolaannya itu kan terbuka, malah dengan tender jadi intinya secara terbuka saja." (Hasil Wawancara dengan Kepala Bidang Pasar Dinas Perdagangan dan Perindustrian Kota Pekanbaru, Bapak Hendra Putra pada tanggal 4 Mei 2021). Menurut pihak swasta PT. Riau Kerta Raharja karyawan bagian operasional pasar sail, beliau menyatakan:

"Gak tau kita perdanya, tapi kalau tahap awal dulu dibangun ada IMB-nya sudah diatur dalam kontrak mulai dari bentuk bangunannya jadi kita mengikuti itu aja." (Hasil wawancara dengan bagian operasional PT. Riau Kerta Raharja pasar Sail, Bapak Malano pada tanggal 7 Mei 2021).

Berdasarkan hasil wawancara dengan Kepala Bidang Pasar DPP Kota Pekanbaru, beliau menyatakan:

"Kalau kondisi pasar Sail, intinya kan kalau kita bicara pada kondisi tahap awal ya mulai dari tahap awak, kalau tidak salah Pasar Sail itu kontraknya 1999, ditandatangani oleh walikota pada saat itu dengan direktur PT. Riau Kerta Raharja. Kemudian mulai dibangun tahun 2000 dan berperasi tahun 2022, kemudian pada saat pembangunannya pasar itu jugak termasuk ya bagus pada masanya. Dengan pengelolaan kepada pihak ketiga kemudian seiring berjalannya waktu kontraknya itu kan selama 20 tahun habis sekitar Mei 2022 nanti. Kemudian memang kondisi pasar saat ini jugak dampak dari ekonomi keseluruhan memang tingkat huniannya sudah berkurang" (Hasil Wawancara dengan Kepala Bidang Pasar Dinas Perdagangan dan Perindustrian Kota Pekanbaru, Bapak Hendra Putra pada tanggal 4 Mei 2021).
Berdasarkan hasil dari wawancara dengan Kepala Bidang Pasar Dinas Perdagangan dan Perindustrian Kota Pekanbaru, beliau menyatakan:

"Kalau yang kita lakukan yaitu memberikan pengelolaan pasar kepada pihak ketiga agar biaya opersional pasar tidak dibebankan kepada APBD tapi pasar tempat berbelanja tetap ada, dan yang akan kita lakukan ke depannya yang pertama antisipasi, sebelum masa berlaku kontrak ini, kita akan meminta laporan tahunan kemuadia laporan tahunan itu akan menjadi bahan evaluasi kita. Kita juga akan menyurati inspektorat Kota Pekanbaru minta dilakukan audit internal yang adek sampaikan tadi berhubungan dengan kelayakan bangunan, Intinya apakah bangunan ini masih layak atau tidak. Kalau untuk keberadaannya pasar terus terang aja kita melihat masih diperlukan buktinya ada aktivitas disana, ada kegiatan bertemunya pembeli dengan pedagang. Kemudian pasar itu diadakan untuk UMKM kita jadi pasar rakyat inilah pedagang yang dikategorikan UMKM bisa berjualan disitu." (Hasil Wawancara dengan Kepala Bidang Pasar Dinas Perdagangan dan Perindustrian Kota Pekanbaru, Bapak Hendra Putra pada tanggal 4 Mei 2021).

Hasil penelitian dari indikator pencapaian target kebijakan (output) dalam jangka pendek, dapat disimpulkan bahwa yang menjadi target dari kebijakan tersebut belum tercapai secara maksimal dari segi sosialisasi yang belum dilakukan pemerintah kepada perusahaan membuat hasil yang diharapkan belum tercapai atau belum efektif. Akan tetapi dari segi efesiensi metode pengelolaan kepada pihak ketiga ini sudah efesien karena anggaran pengelolaan yang tidak lagi dibebankan kepada APBD 
dan pemerintah mendapat royalti dari kerja sama tersebut.

\subsection{Pencapaian Tujuan Kebijakan (Outcome) Dalam Jangka Panjang}

Memiliki arti yaitu dampak atau manfaat yang dihasilkan setelah kebijakan itu dilaksanakan dalam waktu tertentu. Berbeda dengan output yaitu hasil yang langsung diperoleh saat pelaksanaan, sedangkan outcome dampak, pengaruh dan manfaat setelak kebijakan itu dilaksanakan dalam kurun waktu yang cukup lama atau jangka panjang. Biasanya untuk mengetahui outcome dari sebuah program sudah ditentukan pada saat pembuatan waktu untuk mengevaluasi pengenai pelaksanaan program tersebut.

Setelah kebijakan itu dilaksanakan perlu adanya pengawasan dari pengawas kepada pihak yang melaksanakan kebijakan itu. Ada beberapa hal yang harus di perhatikan seperti penentuan target, sasaran da proses pelaksanaannya. Pengawasan harus dilakukan secara berkala dan berkesinambungan yang kemudian di bukukan dalam bentuk laporan tahunan berdasarkan fakta dan data dilapangan.

Berdasarkan hasil dari wawancara dengan Kepala Bidang Pasar Dinas Perdagangan dan Perindustrian Kota Pekanbaru, beliau menyatakan:

\section{"Untuk pengawasannya dari kita} secara operasional kita tetap melakukan pengawasan rutin, termasuk juga dalam situasi wabah pandemi ini kita buat surat edaran, kita lakukan pengawasan juga secara teknis kita juga memantau situasi pasarnya seperti apa, kondisinya mangkanya juga kita sering komunikasi. Laporan perkembangan, situasinya tetap memang secara teknis operasional tetap dibawah pengawasan kita." (Hasil Wawancara dengan Kepala Bidang Pasar Dinas Perdagangan dan Perindustrian Kota Pekanbaru, Bapak Hendra Putra pada tanggal 4 Mei 2021)
Sedangkan menurut pihak pengelola bagian penagihan Pasar Sail dari PT. Riau Kerta Raharja, beliau menyatakan:

"Kalau pengawasan dipasar ada tapi untuk tindakan yang ada disekitar pasar belum ada, kalau untuk peraturan tentang fisiknya 'kan itu perdanya 2014 mungkin untuk pasar yang akan dibangun sedangkan kita kan sudah lama. Tapi kalau target kita bisa memenuhi dengan biaya sewa yang kita dapat sesudah dipotong pajak kita maumau aja bikin sesuai yang ada dalam undang-undang itu tapi kondisi pasar kayak gini kita berat juga" (Hasil Wawancara dengan bagian penagihan Pasar Sail PT. Riau Kerta Raharja, Bapak Ibet pada tanggal 7 Mei 2021)

Berdasarkan hasil dari wawancara dengan Kepala Bidang Pasar Dinas Perdagangan dan Perindustrian Kota Pekanbaru, beliau menyatakan:

"Sebagai Ibukota Provinsi kita terus terang aja memiliki beberapa pasar dan memag terus terang aja ada pasar rakyat yang langsung kita kelola, kalau memang pasar yang kita kelola positifnya ini bisa menampung pedagang yang terus terang aja mereka memiliki modal yang tidak terlalu banyak, kemudian jugak dalam rangka pemberdayakan UMKM. Kemudian yang jelas ada keuntungan kepada PEMKO untuk pasar yang dikelola pihak ketiga yaitu royalti yang sudah disepakati bersama ada yang dibayar di depan ada di bayar pertahun". (Hasil Wawancara dengan Kepala Bidang Pasar Dinas Perdagangan dan Perindustrian Kota Pekanbaru, Bapak Hendra Putra pada tanggal 4 Mei 2021). Hasil penelitian dari indikator pencapaian tujuan kebijakan (outcome) dalam jangka panjang dapat disimpulkan belum maksimal. Untuk ketepatan pengelolan kepada pihak ketiga sebenarnya sudah tepat, hal ini bertujuan memberikan kesempatan kepada swasta mengelola pasar agar mendapat keuntungan dan pemerintah bisa mendapat royalti dari kerjasama 
tersebut. Akan tetapi untuk pengendalian pelaksanaan kebijakan belum ada karena tidak ada sangsi tegas dari pemerintah kepada PT. Riau Kerta Raharja karena tidak menjalankan kebijakan sesuai perda No. 9 tahun 2014 terhadap perencanaan fisik di pasar Sail hingga saat ini.

4.3 Kesenjangan Antara Target Dan Tujuan Dengan Pencapaian

Kesenjangan atau ketidaksesuaian antara harapan dan kenyataan dilapangan terhadap target dan tujuan dalam Peraturan Daerah Kota Pekanbaru No 9 Tahun 2014 tersebut diketahui melalui proses analisa dari respon masyarakat dan pihak ketiga yang belum merasa diuntungkan dari kebijakan ini. Beberapa pihak merasa kebijakan ini belum sesuai dengan usaha pemerintah dalam mendukung tercapainya tujuan yang sudah ditetapkan. Dan respon ini dibuktikan dengan kondisi di lapangan ternyata memang masih ditemukan perlunya perbaikan terutama kondisi fisik pada Pasar Sail.

Berdasarkan hasil dari wawancara dengan Kepala Bidang Pasar Dinas Perdagangan dan Perindustrian Kota Pekanbaru, beliau menyatakan:

"Kalau saran itu bagus, intimya kan jugak sebenarnya manajemen ini jugak harus berkembang mengikuti dinamika perkembangan masyarakat. Jika perlu pasar itu ditata mengikuti perkembangan tetapi juga pada intinya tidak merubah kontruksi awal, tetapi juga diperlukan inovasi-inovasi manajemen mungkin dibuat kayak kedai kopi milenial, arena bermain anak-anak dan itu sah-sah saja. Jadi intinya supaya juga apa? Pengunjung pembeli kesana merasa nyaman". (Hasil Wawancara dengan Kepala Bidang Pasar Dinas Perdagangan dan Perindustrian Kota Pekanbaru, Bapak Hendra Putra pada tanggal 4 Mei 2021). Menurut salah seorang pedagang di Pasar Sail, beliau menyatakan:
"Berharap ada perbaikan sih, tapi kondisi kita dengan pembelinya jugak berkurang mulai sejak banyak pasar kaget. Kalau biaya tak terduka ini oleh pengelola kan ada kasnya sendiri, parkir itu ada setorannya kemaren mau naik tu sedangkan penjualan kita ancur-ancuran". (Hasil Wawancara dengan pedagang Pasar Sail, Ibu Indah pada tanggal 8 Mei 2021).

Menurut pihak swasta PT. Riau Kerta Raharja karyawan bagian operasional pasar Sail, beliau menyatakan:

"Tujuannya emang bagus, tapi kenyataannya dilapangan gak jalan kayak pasar liar inikan kita disuruh buat fasilitas ini itu tapi mereka ada nggak? Kalau gak berarti mereka ilegal. Mereka bikin PERDA kantanya pembuangannya, limbahnya, dampak lingkungan harus selesai. Pajak ditarik tapi kita nggak disuport, kontribusi dari pemerintah untuk kita mana? harusnya sama-sama melaksanakan jangan Cuma menuntut kita”. (Hasil wawancara dengan bagian operasional PT. Riau Kerta Raharja pasar sail, Bapak Malano pada tanggal 7 Mei 2021).

Hasil penelitian dari indikator kesenjangan antara target dan tujuan dengan pencapaian, dapat disimpulkan masih ditemukannya ketidaksesuaian antara keinginan dengan pencapaian terhadap target dan tujuan yang sudah ditetapkan sesuai yang ada di dalam kebijakan tersebut, hal ini disebabkan oleh pemerintah yang tidak tegas kepada PT. Riau Kerta Raharja karena tidak menjalankan perda tentang pengelolaan pasar tersebut. Lalu PT. Riau Kerta Raharja dinilai tidak mampu mengikuti dinamika perkembangan masyarakat dalam mengelola Pasar Sail dengan melakukan inovasi manajemen dan renovasi pasar agar masyarakat tetap berkunjung ke Pasar Sail.

4.4 Membandingkan Kebijakan Yang Sama Di Tempat Yang Berhasil 
Membandingkan ini bermaksud menilai hasil capaian di suatu tempat yang sudah dikategorikan baik dengan tempat yang belum baik pencapiannya. Ada beberapa hal langsung bisa dibandingkan seperti kondisi fisik, respon dari masyarakat atau orang yang terlibat dalam pelaksanaan kebijakan tersebut. Pada proses membandingkan ini dilakukan oleh pihak yang bertanggung jawab pada pengelolaan pasar yaitu oleh DPP, selain dari kondisi fisik ada hal lain yang bisa dijadikan objek saat membandingkan tersebut seperti sistem manajemen yang digunakan pengelola pasar rakyat tersebut.

Berdasarkan hasil dari wawancara dengan Kepala Bidang Pasar Dinas Perdagangan dan Perindustrian Kota Pekanbaru, beliau menyatakan:

"Iya itu tadi perkembangannya, mungkin dari segi pelayanan masyarakat pemerintah mengakomodir, intinya membangun pasar-pasar rakyat kemudian disatu sisi kita jugak berfikir kita perlu menganggandeng pihak ketiga tadi sebagai investor yang berinvestasi dibidang pasar. Kalau dari segi Pasar Sail mungkin pertama manajemen pengelolaannya perlu dilakukan inovasi-inovasi langkah-langkah supaya juga pedagang merasa lebih nyaman, ketertiban termasuk kebersihan". (Hasil Wawancara dengan Kepala Bidang Pasar Dinas Perdagangan dan Perindustrian Kota Pekanbaru, Bapak Hendra Putra pada tanggal 4 Mei 2021).

Dan menurut pihak swasta PT. Riau Kerta Raharja karyawan bagian operasional pasar Sail, beliau menyatakan:

"Kalau untuk kita ya kita masih melakukan pengelolaan seperti biasa sampai kontak kita habis, semampu kita mungkin dari segi kebersihan dan keamanan dibantu petugas karcis". (Hasil wawancara dengan bagian operasional PT. Riau Kerta Raharja pasar Sail, Bapak Malano pada tanggal 7 Mei 2021).
Berdasarkan hasil dari wawancara dengan Kepala Bidang Pasar Dinas Perdagangan dan Perindustrian Kota Pekanbaru, beliau menyatakan:

"Kalau cara pelayananya mungkin hampir sama antara Pasar Lima Puluh dan Pasar Sail yaitu tujuannya untuk masyarakat dengan cara menyediakan tempat berjualan bagi pedagang, tapi kalau prosedur pengelolaannya kita lihat ada perbedaan karena kalau Lima Puluh UPT yang langsung dari DPP berarti mereka mengikuti anjuran langsung dari DPP tentang bagaimana pengelolaannya kayak kalau ada kerusakan biasanya itu dikoordinasikan saja kepada DPP kita perbaiki dengan dana APBD tapi kalau Pasar Sail memang mereka mengelola sendiri tentu mereka punya caranya sendiri, dan untuk sewa sama perbaikan pasti mereka punya kasnya sendiri". (Hasil Wawancara dengan Kepala Bidang Pasar Dinas Perdagangan dan Perindustrian Kota Pekanbaru, Bapak Hendra Putra pada tanggal 4 Mei 2021).

Berdasarkan hasil dari wawancara dengan Kepala Bidang Pasar Dinas Perdagangan dan Perindustrian Kota Pekanbaru, beliau menyatakan:

"Pasar Lima Puluh ini terus terang saja pasar yang dikelola oleh pemko dan menjadi pasar percontohan, kemudian kita berusaha melengkapi sarana san prasarananya disana dan tahun ini jugak Pasar Lima Puluh ini menjadi pasar aman dan sehat dari bahan berbahaya yang mengikuti nominator lomba tingkat nasional. Pasar Sail itu mungkin tinggal renovasi aja dari pihak pengelola mungkin ya kedepan kita melakukan evaluasi. Mungkin kita berharap yang akan mengelola Pasar Sail ini lebih melakukan inovasi dengan manajemen yang lebih baik, kalau untuk keberhasilan kebijakan itukan tergantung pengelolanya mereka 
mampu atau tidak karna ada jugak pasar yang dikelola pihak ketiga tapi bagus pengelolannya”. (Hasil Wawancara dengan Kepala Bidang Pasar Dinas Perdagangan dan Perindustrian Kota Pekanbaru, Bapak Hendra Putra pada tanggal 4 Mei 2021). Hasil penelitian dari indikator membandingkan kebijakan yang sama di tempat yang berhasil, disimpulkan metode yang berbeda yang dilakukan kedua pasar tersebut dimana Pasar Lima Puluh selalu berusaha melakukan inovasi manajemen untuk mengikuti perkembangan masyarakat sehingga Pasar Lima Puluh bisa menjadi pasar percontohan mendapat menghargaan dan menjadi nominasi nasional sebagai pasar yang aman, bersih dan bebas bahan berbahaya. Perlu adanya prosedur pelayanan baik kepada pedagang dan pembeli seperti yang dilakukan Pasar Lima Puluh seperti memberikan fasilitas dan sarana yang baik kepada pedagang dan pengunjung pasar. Hal inilah yang juga harus dilakukan oleh Pasar Sail agar bisa menjadi tempat berjualan yang nyaman dan tertata bagi pedagang dan tempat berbelanja yang diminati pengunjung.

4.5 Identifikasi Faktor Pendukung Keberhasilan Dan Kegagalan Dan Rekomendasi Untuk Mengatasi Kesenjangan

Setelah membandingkan data hasil temuan dilapangan dan data dari sumbernya, hal ini untuk mengetahui apa saja pelaksanaan yang belum terlaksana dan tercapai sesuai PERDA tersebut. Kemudian akan diketahui apa saja faktor pendukung dan penghambat keberhasilan yang akan dievaluasi untuk mengatasi permasalahan tersebut.

Berdasarkan hasil dari wawancara dengan Kepala Bidang Pasar Dinas Perdagangan dan Perindustrian Kota Pekanbaru, beliau menyatakan:

"Kalau kinerja PT-nya kalau saya lihat ya secara umum saat ini terus terang aja kalau kondisi terakhir sekarang ini kurang maksimal, karna pengelola awal yang menanda tangani kontrak awal orangnya sudah meninggal, sekarang tinggal melanjukan mungkin juga karna masa kontrak sudah mau habis kalau kita lihat dari segi perawatannya kurang maksimal itu hambatan kita sekarang ini untuk Pasar Sail". (Hasil Wawancara dengan Kepala Bidang Pasar Dinas Perdagangan dan Perindustrian Kota Pekanbaru, Bapak Hendra Putra pada tanggal 4 Mei 2021).

Berdasarkan hasil dari wawancara dengan Kepala Bidang Pasar Dinas Perdagangan dan Perindustrian Kota Pekanbaru, beliau menyatakan:

"Seperti yang sudah kita katakan tadi bahwa kita akan antiripasti terlebih dahulu dengan meminta laporan tahunanya, kemudian kita juga akan menyurati inspektorat Kota Pekanbaru, minta dilaukan audit internal yang berhubungan dengan kelayakan bangunan apakah masih layak atau tidak. Kemudian berkaitan dengan kerja sama kedepannya itu nanti setelah dilakukan audit menunjuk konsultan apraisal bagaimana sistemnya kedepan, apakah dilelang secara terbuka kemudian dalam aturan itu juga bisa menggunakan pola kerja sama atau disewakan". (Hasil Wawancara dengan Kepala Bidang Pasar Dinas Perdagangan dan Perindustrian Kota Pekanbaru, Bapak Hendra Putra pada tanggal 4 Mei 2021). Hasil penelitian dari indikator identifikasi faktor pendukung keberhasilan dan kegagalan dan rekomendasi untuk mengatasi kesenjangan, dapat disimpulkan bahwa faktor internar organisasi kinerja PT. Riau Kerta Raharja dinilai kurang baik dalam mengelola Pasar Sail dilihat dari kondisi fisik Pasar Sail saat ini. Faktor lain yaitu masa kontrak yang akan segera habis anatar pemerintah dan PT. Riau Kerta Raharja membuat belum bisa melakukan 
perbaikan terhadap Pasar Sail, selain itu faktor eksternal yaitu keberadaan pasar kaget yang belum terselesaikan oleh pemerintah. Untuk mengatasi kesenjangan tersebut maka akan dilakukan evaluasi terhadap PT. Riau Kerta Raharja dalam mengelola Pasar Sail lalu dilakukan pelelangan terbuka untuk pengelolaan Pasar Sail kedepannya.

Hasil penelitian tentang Evaluasi Peraturan Daerah Kota Pekanbaru No. 9 Tahun 2014 Tentang Pengelolaan Pasar Rakyat, Pusat Perbelanjaan dan Toko Swalayan Pada Dinas Perdagangan dan Perindustrian Terhadap Perencanaan Fisik Pasar Sail di Kecamatan Sail yaitu kebijakan ini belum berjalan dengan baik dan efektif terhadap kondisi fisik Pasar Sail saat ini. Hal ini diketahui dari temuan penulis dilapangan serta data yang diperoleh dari informan bahwa fasilitas dan sarana prasarana yang ada di Pasar Sail belum lengkap sesuai yang ada dalam Perda No. 9 tahun 2014, hal lain yang ditemui yaitu kondisi kios dan los serta bangunan yang perlu adanya perbaikan. Artinya Dinas Pedagangan dan Perindustrian belum melakukan tugas dan fungsinya dengan baik dalam mengelola pasar yang ada di Kota Pekanbaru khususnya Pasar Sail mewujudkan tujuan dalam Peraturan Daerah untuk menciptakan pasar yang amansehat dan memiliki fasilitas yang lengkap.

Hambatan dan kendala yang ditemui pemerintah Kota Pekanbaru dalam merealisasikan Peraturan Daerah Kota Pekanbaru No. 9 Tahun 2014 tentang pengelolaan pasar rakyat, pusat perbelanjaan dan toko swalayan terhadap perencanaan fisik pasar Sail di Kecamatan Sail.

1. Kurang sosialiasasi

Kurangnya sosialisasi dari pemerintah tentang adanya Peraturan Daerah No. 9 Tahun 2014. Kepada pihak PT. Riau Kerta Raharja sebagai pengelola Pasar Sail yang hingga saat diwawancarai menyebutkan tidak mengetahui tentang adanya peraturan pengelolaan pasar tersebut. (Dibuktikan berdasarkan wawancara dengan salah seorang karyawan PT. Riau Kerta Raharja, Bapak Malano pada tanggal 7 Mei 2021).

2. Belum ada ketegasan sangsi

Hingga saat ini belum adanya ketegasan sangsi yang diberikan dari pemerintah kepada perusahaan yang tidak menjalankan peraturan Daerah Kota Pekanbaru No 9 Tahun 2014 tersebut. Dalam hal ini PT. Riau Kerta Raharja sebagai investor sekaligus pengelola pasar Sail. (Dibuktikan berdasarkan wawancara dengan Kepala Bidang Pasar Dinas Perdagangan dan Perindustrian Kota Pekanbaru, Bapak Hendra Putra pada tanggal 4 Mei 2021).

\section{Kesimpulan}

Berdasarkan hasil penelitian tentang Evaluasi Peraturan Daerah Kota Pekanbaru No. 9 Tahun 2014 Tentang Pengelolaan Pasar Rakyat,Pusat Perbelanjaan Dan Toko Swalayan Pada Dinas Perdagangan Dan Perindustrian (Studi Kasus Perencanaan Fisik Pasar Sail Di Kecamatan Sail) yang dibahas pada bab sebelumnya, maka dapat ditarik kesimpulan sebagai berikut :

1. Pelaksanaan tugas dan fungsi Dinas Perdagangan dan Perindustrian sebagai Dinas yang bertanggung jawab mengenai pengelolaan pasar sesuai Peraturan Daerah Nomor 9 Tahun 2014 terhadap Perencanaan fisik Pasar Sail di Kecamatan Sail belum melakukan tugas dan fungsinya dengan baik dalam mengelola pasar yang ada di Kota Pekanbaru khususnya Pasar Sail untuk mewujudkan tujuan yang ada dalam peraturan daerah tersebut dalam rangka mewujudkan pasar yang aman, sehat dan memiliki falisitas yang lengkap. Masih banyak fasilitas dan sarana pendukung yang tidak tersedia di Pasar Sail, serta tidak adanya tindakan tegas atau sangsi yang diberikan kepada pihak yang tidak melaksanakan atau menjalankan kebijakan tersebut.

2. Hambatan Dalam Pelaksanaan Peraturan Daerah Kota Pekanbaru No 9 Tahun 2014 Tentang Pengelolaan Pasar Rakyat, Pusat Perbelanjaan dan Toko Swalayan Pada Dinas Perdagangan dan Perindustrian 
(Studi Kasus Perencanaan Fisik Pasar Sail Di Kecamatan Sail).

a. Dinas Perdagangan dan Perindustrian kurang mengsosialisasikan Peraturan Daerah No. 9 Tahun 2014 tentang pengelolaan pasar rakyat, pusat perbelanjaan dan toko swalayan.

b. Dinas Perdagangan Dan Perindustrian dalam menjalankan Peraturan Daerah No. 9 Tahun 2014.tentang pengelolaan pasar rakyat, pusat perbelanjaan dan toko swalayan belum terlaksananya ketegasan bagi yang tidak menjalankan peraturan tersebut.

\section{Daftar Pustaka}

Ahmad, J. (2015). Metode penelitian administrasi publik teori dan aplikasi. Yogyakarta: Gava Media.

Algifari. (2002). Ekonomi Mikro Teori Dan Kasus Edisi Kesatu.Yogyakarta: STIE YKPN

Ali, F. (2011). Teori dan Konsep Administrasi. Jakarta: $\quad P T \quad$ Raja Grafindo.

Ambarwati, A. (2018). Perilaku Dan Teori Organisasi.

Anggara, S. (2012). Ilmu Administrasi Negara: Kajian Konsep, Teori, dan Fakta Dalam Upaya Menciptakan Good Governance (Vol. 1). CV Pustaka Setia.

Gunawan, I. (2016). Metode Penelitian Kualitatif: Teori dan Praktik. Edisi kesatu, Cetakan keempat. PT. Bumi Aksara. Jakarta.

Hardani, dkk. (2020). Metode Penelitian Kualitatif dan kuantitatif. Yogyakarta : CV.Pustaka Ilmu Grup

Nugroho, R. (2020). PUBLIC POLICY 6Edisi Revisi. Elex Media Komputindo.

Pasolong, H. (2013). Teori Administrasi Publik, Cetakan Kelima, CV. Alfabeta, Bandung.
Peraturan Daerah Kota Pekanbaru Nomor 9 Tahun 2014 Tentang Pengelolaan Pasar Rakyat, Pusat Perbelanjaan dan Toko Swalayan.

Rahardjo, A. (2011). Pengelolaan pendapatan dan anggaran daerah. Yogyakarta: Graha Ilmu.

Relawati, R. (2012). Dasar Manajemen Pendekatan Aplikasi Bidang Pertanian.

Siagian, S. P. (2011). Filsafat administrasi.

Sudaryono, D. (2016). Manajemen Pemasaran teori dan implementasi. Yogyakarta: Andi.

Sugiyono, Prof. "Metode penelitian kombinasi (mixed methods)." Bandung: $\quad$ Alfabeta 28 (2015): 1-12.

Sutarmadi, A., Rudiatin, E., \& Muh. Fudhail Rahman. (2012). Manajemen Masjid Kontemporer. Penerbit Media Bangsa.

Yandra, A. (2016). Partisipasi Masyarakat dalam Penyusunan Rencana Pembangunan Jangka Menengah Daerah (RPJMD) Kota Pekanbaru 2012-2017. PUBLIKA: Jurnal Ilmu Administrasi Publik, 2(1), 48-58. 